\title{
Suomalaisten lääkäreiden ja hammaslääkäreiden terveydenhuollon tietotekniikan erityispätevyys: tavoitteet, sisältö ja ensikokemukset
}

Jarmo Reponen, LT, professori (ma)

FinnTelemedicum, Lääketieteellisen kuvantamisen, fysiikan ja tekniikan tutkimusryhmä, Oulun yliopisto; Röntgenosasto, Raahen sairaala, Raahen seudun hyvinvointikuntayhtymä

Professori Jarmo Reponen, FinnTelemedicum, Lääketieteellisen kuvantamisen, fysiikan ja tekniikan tutkimusryhmä, PL 5000, FI-90014 Oulun yliopisto, FINLAND. Sähköposti: jarmo.reponen@oulu.fi.

\section{Tiivistelmä}

Terveydenhuollon tietotekniikan (e-terveyspalvelujen) ammatillinen erityispätevyys edistää lääkärien ja hammaslääkärien kiinnostusta ja sitoutumista terveydenhuollon tietoteknologian hyödyntämiseen ja sähköisten terveyspalvelujen kehittämiseen. Suomi perusti tämän erityispätevyyden ensimmäisenä maana Euroopassa lääkäreille joulukuussa 2012, hammaslääkärit liittyivät mukaan vuonna 2015. Pätevyyden saavuttaminen edellyttää yhteensä kahden vuoden työskentelyä sähköisten terveyspalvelujen alalla sekä teoreettisia opintoja. Pohjakoulutuksena edellytetään pääsääntöisesti erikoislääkärin tutkintoa ja osaaminen osoitetaan rakenteisella portfoliolla. Tavoitteena on siten tarjota pätevöitymismahdollisuutta jo käytännön työssä kokeneille toimijoille. Koulutukseen oli vuoden 2016 loppuun mennessä ilmoittautunut yhteensä 87 henkeä ja pätevyyden oli näistä jo loppuun suorittanut 58 lääkäriä ja 3 hammaslääkäriä. Valmistuneet saavat valmiudet toimiakseen johtavina asiantuntijoina tai hallinnollisissa tehtävissä kehitettäessä sähköisten tai mobiilien terveyspalvelujen prosesseja alueellisissa tai kansallisissa hankkeissa. Erityispätevyydestä vastaavat yhdessä Suomen telelääketieteen ja eHealth seura, Suomen Lääkäriliitto ja Suomen Hammaslääkäriliitto.

Avainsanat: telelääketiede, lääketieteellinen informatiikka, koulutus, ammatillinen pätevyys

\begin{abstract}
Finland was to our knowledge the first country in Europe to establish a professional special competence for healthcare information technology (eHealth) since 2012 to physicians and since 2015 to dentists. The special competence requires two year full time service and theoretical studies after a qualified medical specialist consultant status. Those who have earned the title are thus already experienced medical doctors and dentists. The new competence gives them an ability to utilize their knowledge about health care processes for the benefit of the new eHealth and mHealth services. By the end of year 2016 total 87 professionals have been enrolled to the program and 58 physicians and 3 dentists have already graduated. Those graduated have found positions as leading healthcare information technology experts or in administrative tasks in regional or national eHealth and $\mathrm{mHealth}$ projects. The special competence program is a joint effort of Finnish Society of Telemedicine and eHealth, Finnish Medical Association and Finnish Dental Association.
\end{abstract}

Keywords: telemedicine, medical informatics, education, professional competence 


\section{Johdanto}

Tämän vuosituhannen alusta alkaen terveydenhuollon tieto- ja viestintäteknologiasta on tullut lääkärin perustyökalu ja terveydenhuollon strateginen muutosvoima. Erityispätevyys terveydenhuollon tietotekniikkaan ja sähköisiin terveyspalveluihin (eHealth) tarvitaan täydentämään sitä koulutustarvetta, jota nykyiseen erikoislääkärikoulutukseen ei sisälly. Tällä hetkellä Suomen julkisessa terveydenhuollossa käytetään kaikissa perusterveydenhuollon ja erikoissairaanhoidon yksiköissä sähköisiä sairaskertomusohjelmistoja ja niiden levinneisyys on lähes 100 \% myös yksityisten toimijoiden toimipisteistä [1]. Sähköinen resepti on maassamme kattavasti käytössä ja valtakunnallinen terveystiedon arkisto kattaa pian paitsi julkisen terveydenhuollon toimijat, myös yksityisen terveydenhuollon [2]. Telelääketiede ja e-terveyspalvelujen ratkaisut ovat keskeinen osa terveydenhuollon organisaatioita ja prosesseja. Ne ulottuvat nykyisellään ammattilaisten välisistä konsultaatiopalveluista asiakkaille suunnattuihin suoriin palveluihin ja omahoitoratkaisuihin [3]. Uusimman kansallisen sosiaali- ja terveydenhuollon tietoteknologiastrategian tavoitteena on tukea sosiaali- ja terveydenhuollon uudistamista ja kansalaisten aktiivisuutta oman hyvinvointinsa ylläpidossa parantamalla tiedonhallintaa ja lisäämällä sähköisiä palveluja. Strategian tavoitteisiin pääsemiseksi tarvitaan lisäksi uutta osaamista, jotta sosiaali- ja terveydenhuollossa kertyvää tietoa voidaan jalostaa tietämykseksi, joka auttaa niin palvelujärjestelmää kuin yksittäistä kansalaistakin. [4]

Korkeimmin koulutettuina terveysalan ammattilaisina lääkärien ja hammaslääkärien panos terveydenhuollon tietotekniikan ja sähköisten terveyspalvelujen kehittämisessä ja käyttöönotossa tulee jatkossa olemaan ratkaiseva [5]. Tietojärjestelmien käytettävyystutkimukset ovat osoittaneet lääkärien suuremmalle osallistumiselle olevan tarvetta tietojärjestelmien puutteiden korjaamisessa [6, 7]. Tähän asti vaikuttaminen on usein perustunut omaan kiinnostukseen ja harrastuneisuuteen, varsin harvoilla lääkäritoimijalla on lääketieteen koulutuksen lisäksi muuta koulutusta tieto- ja viestintäteknologian alalta. Terveydenhuollon tietotekniikan (eterveyspalvelujen) erityispätevyyden tavoitteena on luoda asiantuntijalääkärien ja asiantuntijahammaslää- kärien verkosto, joka toimii alan yritysten, tutkimuslaitosten ja muiden toimijoiden yhteistyökumppanina. Terveydenhuollon tietotekniikan erityispätevyys tarjoaa lääkäreille ja hammaslääkäreille jäsennellyn, nykyaikaisen tavan kehittää osaamistaan terveydenhuollon tietotekniikassa ja tiedonhallinnassa sekä motivoivan urakehitysmahdollisuuden. Tietotekniikan erityispätevyys ei korvaa tiedonhallinnan maisteriohjelmia, vaan tarjoaa mahdollisuuden ammatilliseen suuntautumiseen lisäkoulutuksen kautta. Terveydenhuollon prosessien tuntemus antaa valmiuksia soveltaa uusia sähköisiä työvälineitä potilaiden hoidossa ja kykyä johtaa niiden käyttöönottoon liittyviä toiminnan muutoksia. Tietotekniikan erityispätevyys on yksi 31:stä tällä hetkellä voimassa olevasta Lääkäriliiton erityispätevyysohjelmasta [8].

\section{Koulutusohjelman sisältö}

Erityispätevyyden omaavan tulee olla pohjakoulutukseltaan Suomessa laillistettu lääkäri tai hammaslääkäri. Pääsääntöisesti edellytetään erikoislääkärin pätevyyttä. Erityispätevyys voidaan poikkeuksellisesti myöntää myös hakijalle, jolla ei ole erikoislääkärin pätevyyttä, mutta joka muuten ansioiltaan täyttää erityispätevyyden edellytykset. Kuitenkin edellytetään vähintään viiden vuoden kokemusta lääkärin työstä valmiina lääkärinä.

Varsinainen erityispätevyyden kerryttäminen koostuu kahden vuoden palveluista toimialan tehtävissä sekä erityispätevyyden ohjeissa määritellyistä teoreettisista koulutuksista. Palvelujen tulee olla monipuolisia kehittämis- koulutus- ja tutkimustehtäviä, pelkkä jonkin tietojärjestelmän käyttö tai käytön ohjaus pääkäyttäjänä ei riitä palveluksi. Palvelut voi suorittaa myös osaaikaisissa toimissa, silloin palvelujen ajan ja sisällön on oltava dokumentoitavissa. Teoreettisissa koulutuksissa suositetaan alan oppilaitosten koulutustarjontaa, mutta niitä voi kerätä myös konferensseissa ja lyhyemmissä koulutustapahtumissa. Koulutuksiin tulee sisällyttää osallistuminen kansainvälisiin e-terveyspalvelujen (eHealth) kongresseihin. Alan tutkimustyöllä voi myös korvata osan vaatimuksista, esimerkiksi akateeminen 
väitöskirja kohdealueelta vastaa puolen vuoden palvelua.

Koska erityispätevyydestä ei vaadita tenttiä, on tärkeää kuvata koulutuksen suorittaminen ja oma osaaminen tarkasti erikseen laadittavaan portfolioon, jonka tarkas tavat nimetyt asiantuntijat ja jonka perusteella erityispätevyystoimikunta tekee esityksensä. Portfoliopohjan saa ladattua Suomen Lääkäriliiton erityispätevyyssivuilta verkosta ja sitä käytetään hyväksi erityispätevyysohjelmaan ilmoittautuessa, opastuksena suoritusten keräämiseen ja lopulta pätevyyttä haettaessa. Yksityiskohtaisemmat toimintaohjeet löytyvät Lääkäriliiton verkkosivujen oppaista [9].

\section{Tähänastiset tulokset}

Joulukuun 2016 loppuun mennessä erityispätevyysohjelmaan hakeneita oli yhteensä 87, joista 82 lääkäriä ja viisi hammaslääkäriä. Lääkäreistä suurin osa oli hankkinut palvelunsa joulukuussa 2015 päättyneillä siirtymäsäännöksillä, joissa hyväksyttiin laajasti aikaisempia palveluita. Hammaslääkärit pääsivät mukaan ohjelmaan lokakuusta 2015 lähtien ja heillä siirtymäkausi jatkuu kolme vuotta lokakuuhun 2018. Myönnettyjä erityispätevyyksiä oli joulukuun 2016 lopussa 61, joista lääkäreillä 58 ja hammaslääkäreillä kolme.

Erityispätevyyteen johtaneita palveluita oli kerrytetty monipuolisesti eri tehtävissä, suurella osalla oli palvelua erilaisissa tietotekniikan ja ohjelmistoalan projekteissa, mutta mukana on myös tietohallintolääkärin, järjestelmä- ja palvelukehittäjän, kaupallisen yrityksen sekä tutkimuksen ja koulutuksen tehtävissä toimineita. Vuoden 2017 alussa lisäsuorituksia koulutusohjelmassa portfolioonsa keräsi 24 lääkäriä ja kaksi hammaslääkäriä. Suoritusten arviointi on tehty kahden asiantuntijan toimesta ja erityispätevyyden edellytyksien täyttymisestä on päätetty Suomen telelääketieteen ja eHealth seuran asettamassa toimikunnassa. Erityispätevyydet ovat toimikunnan esityksestä myöntäneet Suomen Lääkäriliitto ja Suomen Hammaslääkäriliitto jäsenilleen.

\section{Tulevaisuuden näkymät}

Lääkäreiden osalta erityispätevyys suoritetaan jatkossa henkilökohtaisen kouluttautumisohjelman mukaisesti. Siksi koulutukseen tuleva saa tuekseen oman mentorin aiemmista pätevyyden suorittaneista. Pätevöityjän oma portfolio on keskeinen työväline, siksi sitä on kehitetty ohjaamaan kouluttautumista aiempaa tarkemmin. Teoreettiset koulutukset ovat tähän mennessä pätevöityneillä koostuneet varsin pienistä osioista, joten toimikunta koostaa tietopaketin helpottamaan pätevöityjien valintoja ja ohjaamaan hakeutumaan suurempiin koulutuskokonaisuuksiin. Samalla pyritään säilyttämään joustavuus koulutusten hyväksymisessä, kunhan sisältö on riittävän laadukasta. Jatkossa toivotaan yliopistojen ja ammattikorkeakoulujen e-terveyspalvelujen koulutusten kehittyvän ja ottavan huomioon ammatillisten jatko-opiskelijoiden tarpeet. Verkko-oppimista käyttävät kurssit soveltuisivat erityisen hyvin tämän erityispätevyyden opinnoiksi. Hammaslääkärien osalta otetaan heidän erityistarpeensa huomioon suoritusten keräämisessä, heiltä ei esimerkiksi vaadita erikoishammaslääkärin tutkintoa, mikäli työkokemus on muutoin riittävä.

Terveydenhuollon ammattilaisten osaaminen on saatu parempaan käyttöön tietotekniikan erityispätevyyden kautta nykyisessä tilanteessa, jossa tietojärjestelmät ovat keskeinen muutoksen mahdollistaja. Saadun palautteen perusteella moni nyt pätevyyden suorittanut on hakeutunut johtaviin asiantuntijatehtäviin tai esimiesasemaan. Koulutuksen edelleen kehittämiseksi olisi tärkeää tutkia tarkemmin tätä sijoittumista ja kerätä erityispätevyyskoulutuksen läpäisseiltä palautetta työelämävastaavuudesta. Terveydenhuollon prosessiosaamisella on keskeinen asema sote-uudistuksen ja kansalaisille tuotettujen mobiilien terveyspalvelujen toteuttamisessa. Jatkossa on tarpeen tuoda sähköisten terveyspalvelujen opetus osaksi jo lääkäreiden ja hammaslääkäreiden perusopetusta. Oulun yliopistossa lääkärien peruskoulutuksessa on jo otettu tähän ensi askeleet [10]. Sähköisten terveyspalvelujen tuominen tutuksi jo opiskeluaikana luo myöhemmin työelämässä mahdollisuuden uusiin toimintamalleihin sekä innovaatioihin yhdessä alan yritysten kanssa. 


\section{Kiitokset}

Kiitokset ylilääkäri, LL Eila Erkkilälle Oulun kaupungista ja ylilääkäri, LT Mirja Tuomivaaralle Etelä-Pohjanmaan sairaanhoitopiiristä saumattomasta yhteistyöstä koulutusohjelman valmistelussa.

\section{Lähteet}

[1] Reponen J, Kangas $M$, Hämäläinen $P$, Keränen $N$. Tieto- ja viestintäteknologian käyttö terveydenhuollossa vuonna 2014. Tilanne ja kehityksen suunta. (English abstract: Use of information and communication technology in Finnish health care in 2014. Current situation and trends.) Raportti 12/2015. Helsinki: Terveyden ja hyvinvoinnin laitos (THL); 2015. Saatavilla: http://urn.fi/URN:ISBN:978-952-302-486-1 (luettu 19.3.2017).

[2] Hyppönen H, Hämäläinen $P$, Reponen J (eds.). Ehealth and e-welfare of Finland. Check point 2015. Report 18/2015. Helsinki: National Institute for Health and Welfare (THL); 2015. Saatavilla: http://urn.fi/URN:ISBN:978-952-302-563-9 (luettu 19.3.2017).

[3] Reponen J. Terveydenhuollon sähköiset palvelut murroksessa. Pääkirjoitus. Duodecim 2015;131(13):1275-6.

[4] Tieto hyvinvoinnin ja uudistuvien palvelujen tukena Sote-tieto hyötykäyttöön -strategia 2020. Helsinki: Sosiaali- ja terveysministeriö (STM); 2014. Saatavilla: http://urn.fi/URN:ISBN:978-952-00-3548-8 (luettu 19.3.2017).

\section{Sidonnaisuudet}

Jarmo Reponen on lääkäreiden ja hammaslääkäreiden terveydenhuollon tietotekniikan erityispätevyystoimikunnan puheenjohtaja ja on toiminut Suomen telelääketieteen seuran puheenjohtajana ja Suomen Lääkäriliiton e-Health valiokunnan jäsenenä hankkeen valmistelun aikana.

[5] Reponen J, Tuomiranta M, Erkkilä E. TerveydenhuolIon tietotekniikasta erityispätevyysohjelma. Suomen Lääkärilehti 2013;68(13-14):1031-1033.

[6] Viitanen J, Hyppönen H, Lääveri T, Vänskä J, Reponen J, Winblad I. National questionnaire study on clinical ICT systems proofs: physicians suffer from poor usability. Int J Med Inform 2011;80(10):708-25. https://doi.org/10.1016/i.ijmedinf.2011.06.010

[7] Kaipio J, Lääveri T, Hyppönen $H$, Vainiomäki S, Reponen J, Kushniruk A et al. Usability problems do not heal by themselves: National survey on physicians' experiences with EHRs in Finland. Int J Med Inform 2017;97(1):266-281.

https://doi.org/10.1016/i.ijmedinf.2016.10.010

[8] Suomen Lääkäriliitto. Lääkäriliiton erityispätevyysjärjestelmä.

Saatavilla: https://www.laakariliitto.fi/koulutus/erityispatevyydet/ (luettu 19.3.2017).

[9] Suomen Lääkäriliitto. Terveydenhuollon tietotekniikka.

Saatavilla: http://www.laakariliitto.fi/koulutus/erityispatevyydet/ti etotekniikka/ (luettu 19.3.2017).

[10] Toikkanen U. Lääkäriopiskelijat ideoivat terveysteknologiaa Oulussa. Suomen Lääkärilehti 2016;71(34):2024. 